\title{
Construction of hypermedia for prevention of bloodstream infection
}

\author{
Construção de hipermídia para prevenção de infecção da corrente sanguínea \\ Construcción de hipermedia para la prevención de infección de la corriente sanguínea
}

Isabel Cussi Brasileiro Dias'
ORCID:0000-0002-2638-1054

Eliane de Fátima Almeida Lima'

ORCID: 0000-0001-5128-3715

Mirian Fioresi'

ORCID:0000-0002-8560-4385

Dirceu Carrara"

ORCID: 0000-0002-8708-7414

Izabella Soares de Oliveira' ORCID: 0000-0003-1708-2703

Candida Caniçali Primo'

ORCID: 0000-0001-5141-2898

'Universidade Federal do Espírito Santo. Vitória, Espírito Santo, Brazil. "Universidade de São Paulo, Hospital das Clínicas, Instituto do Coração. São Paulo, São Paulo, Brazil.

How to cite this article: Dias ICB, Lima EFA, Fioresi M, Carrara D, Oliveira IS, Primo CC. Construction of hypermedia for prevention of bloodstream infection. Rev Bras Enferm. 2020;73(6):e20190593. doi: http://dx.doi.org/10.1590/0034-7167-2019-0593

Corresponding author: Isabel Cussi Brasileiro Dias E-mail: isacussi2012@gmail.com

EDITOR IN CHIEF: Antonio José de Almeida Filho ASSOCIATE EDITOR: Ana Fátima Fernandes

Submission: 11-03-2019

Approval: 04-13-2020

\section{ABSTRACT}

Objective: To describe the process of construction and assessment of the content of a Virtual Learning Object on preventing bloodstream infections associated with infusion therapy. Method: Methodological study carried out in three stages: elaborating the technical, scientific content; assessing theoretical content; and constructing the Virtual Learning Object. Results: We produced the theoretical content of the Virtual Learning Object. Such content obtained an $85 \%$ agreement in assessment, which was adequate. The final product comprised 39 content screens, which integrate the main recommendations and contain images, hypertexts, videos, case studies, and quiz, through an exclusive platform. Final Considerations: This study made it possible to portray the method for constructing and assessing the content of a Virtual Learning Object, enabling am easy application to health professionals, aiming at guiding them to quality care.

Descriptors: Hypermedia; Infection; Infection Control; Educational Technology; Education, Nursing.

\section{RESUMO}

Objetivo: Descrever o processo de construção e avaliação do conteúdo de um Objeto Virtual de Aprendizagem sobre prevenção de infecção da corrente sanguínea associada à terapia infusional. Método: Estudo metodológico realizado em três etapas: elaboração do conteúdo técnico científico; avaliação do conteúdo teórico; e construção do Objeto Virtual de Aprendizagem. Resultados: Foi realizada a produção do conteúdo teórico do Objeto Virtual de Aprendizagem. Tal conteúdo obteve avaliação com concordância de $85 \%$, sendo considerado adequado. $O$ produto final foi organizado em 39 telas de conteúdo, que integram as principais recomendações e contêm imagens, hipertextos, vídeos, estudos de casos e quiz, por meio de uma plataforma exclusiva. Considerações finais: Este estudo possibilitou retratar o método para construção e avaliação do conteúdo de um Objeto Virtual de Aprendizagem, viabilizando uma aplicação facilitadora aos profissionais da saúde, visando à orientação para um cuidado com qualidade.

Descritores: Hipermídia; Infecção; Controle de Infecções; Tecnologia Educacional; Educação em Enfermagem.

\section{RESUMEN}

Objetivo: Describir el proceso de construcción y evaluación del contenido de un Objeto Virtual de Aprendizaje sobre prevención de infección de la corriente sanguínea asociada a la terapia de infusión. Método: Estudio metodológico realizado en tres etapas: elaboración del contenido técnico científico; evaluación del contenido teórico; y construcción del Objeto Virtual de Aprendizaje. Resultados: $\mathrm{Ha}$ sido realizada la producción del contenido teórico del Objeto Virtual de Aprendizaje. Tal contenido obtuvo evaluación con concordancia de $85 \%$, siendo considerado adecuado. El producto final ha sido organizado en 39 telas de contenido, que integraron las principales recomendaciones y contienen imágenes, hipertextos, vídeos, estudios de casos y concurso, por medio de una plataforma exclusiva. Conclusiones: Este estudio ha posibilitado retratar el método para construcción y evaluación del contenido de un Objeto Virtual de Aprendizaje, haciendo viable una aplicación facilitadora a los profesionales de la salud, visando a la orientación para una atención con calidad.

Descriptores: Hipermidia; Infección; Control de Infecciones; Tecnología Educacional; Enseñanza en Enfermería. 


\section{INTRODUCTION}

The control and prevention of Health Care Related Infections (HAls) are one of the main concerns related to patient safety since they are the prevalent adverse events in health care ${ }^{(1)}$. Among the HAls that affect hospitalized patients, bloodstream infection is one of the most frequent ${ }^{(2)}$. It is considered a severe infectious disease caused by the invasion of microorganisms in the circulating blood, which leads to the risk of carrying microorganisms to other organs ${ }^{(3)}$. For this reason, preventive measures should be focused on care for the insertion and maintenance of central venous access and peripheral venous access, as both are susceptible to attributable comorbidities and mortality ${ }^{(4)}$.

Infusion therapy is performed through central and peripheral venous accesses, and it includes the administration of solutions, medications, nutritional products, blood, and blood products. It is applied in $50 \%$ or more of hospitalized patients, mainly through the peripheral catheter ${ }^{(5)}$.

The essential recommendations to prevent bloodstream infections associated with venous catheter permeate five courses of action: education, surveillance, aseptic technique, inspection, insertion, and maintenance ${ }^{(6-7)}$. Therefore, there is consensus that educational interventions and the training of health professionals result in the reduction of these diseases since several studies report weaknesses in the knowledge and clinical practice of health professionals concerning measures for preventing and controlling infections related to health care $^{(8)}$.

Among the teaching materials based on educational technologies, we highlight the Virtual Learning Object (VLO). It is a digital resource of limited size possible to apply within various activities and pedagogical strategies. VLO has educational contents and animations, permeated by interdisciplinarity, interactivity, as well as complements and exercises ${ }^{(9-11)}$.

Innovative and participatory methodologies that use educational technologies to disseminate recommendations for good practice have shown positive results in nursing education when validated for its efficiency ${ }^{(12-13)}$.

\section{OBJECTIVE}

To describe the process of construction and assessment of the content of a Virtual Learning Object on preventing bloodstream infection associated with infusion therapy.

\section{METHODS}

\section{Ethical aspects}

This study was approved by the Comissão Nacional de Ética em Pesquisa (CONEP -Research Ethics Commission), under Certificado de Apresentação para Apreciação Ética (CAAE - certificate of presentation for ethical appreciation ).

\section{Theoretical-methodological framework}

The user-centered design method was in accordance with the ABNT ISO-TR 16982:2014(14), designed to construct a Virtual Learning Object.

\section{Study type and target audience}

This research is a methodological study related to the construction of a Virtual Learning Object, an online course, which followed the criteria of the COREQ checklist (Consolidated Criteria for Reporting Qualitative Research) in the research organization.

The online course targets professionals and nursing and medical teams of universities.

\section{Methodological procedures}

\section{Study scenario}

The study was conducted in partnership between a university hospital, the Graduate Program in Nursing, Laboratório de Tecnologias em Saúde e Enfermagem (CuidarTech - Health and Nursing Technologies Laboratory) and the Laboratório e Observatório de Ontologias Projetuais (LOOP - Laboratory and Observatory of Projecting Ontologies), linked to the Federal University of Espírito Santo (UFES)

\section{Work stages}

The work was developed in three stages: 1) elaborating the theoretical content, 2) assessing theoretical content, and 3) constructing the Virtual Learning Object.

\section{1) Elaborating the theoretical content of the Virtual Learn- ing Object}

In the first stage, based on meetings with the hospital infection control committee, the needs of the hospital institution related to infusion therapy were raised. The demands associated with the specificity of the care provided by the hospital with different clinical profiles.

We used for the elaboration of the textual script, the recommendations of the Brazilian Health Regulatory Agency (ANVISA), the World Health Organization (WHO), the Centers for Disease Control and Prevention (CDC) and the Infusion Nurses Society - Brazil (INS-Brazil), to explore the main preventive measures.

\section{2) Assessing the theoretical content of the Virtual Learn- ing Object}

The second stage, assessing the theoretical content, had the collaboration of the judges and occurred in August and September 2018 , from two Delphi steps. The inclusion criteria to compose the group of specialists were being a nurse or doctor with at least two years of work experience in the area of infection control related to health care; or being a nurse of the care team, with work experience of at least two years in vascular catheters. The exclusion criterion was the absence during the Delphi steps. We used for the selection of judges, two strategies: indication of experts from the researchers' relational universe and the "snowball" technique.

The 11 selected judges received an invitation letter with the presentation of the research and its objectives, the Free and Informed Consent Form (TCLE), and the first version of the theoretical content of the Virtual Learning Object. 
For Delphi Step 1, the electronic application form in Google Forms was sent to be answered, with two distinct sections to fill out: characterization of the specialists; and assessment of the theoretical content of the Virtual Learning Object modules, through a Likert scale with the alternatives "adequate,"'partially adequate" and "inadequate," as well as space to comments or suggestions for adequacy.

To evaluate the degree of specialists' agreement in the Delphi Step 1, we used the Percent Agreement method, considering acceptable an agreement rate among judges of $80 \%{ }^{(15)}$. For Delphi Step 2, a meeting was held with the invited experts to argue the points that were considered "inappropriate" and "partially adequate" of the content presented. After evaluating the content, the standard script was elaborated to organize texts and multimedia (images and videos). Of the invited experts, eight participated in Delphi Steps 1 and 2.

\section{3) Constructing the Virtual Learning Object}

The third stage covered the construction of the Virtual Learning Object according to four phases, according to the ABNT ISO-TR 16982:2014 standard: defining requirements de and elaborating the structure of the Virtual Learning Object; generating implementation and prototyping alternatives; tests; and implementing.

\section{RESULTS}

The theoretical content of the Virtual Learning Object was divided into five major themes, in addition to the presentation and conclusion modules (Chart 1).

Eight judges performed the assessment stage of the theoretical content of the Virtual Learning Object, six of them nurses (75\%), and two physicians (25\%). Regarding the profile of the specialists, six (75\%) were under 40 years old; and two (25\%) over 40 years old, and seven (87.5\%) are female. The length of professional experience ranged from 3 to 24 years, with an average of 12.8 years. Regarding academic titles, four (50\%) had a master's degree, and four (50\%), specialization. The areas of activity varied between hospital infection control committee (3; 37.5\%), ICU - adult and neonatal $(3 ; 37.5 \%)$, Assistencial Risks management $(1 ; 12.5 \%)$ and Oncology $(1 ; 12.5 \%)$.

The screens considered valid regarding their content in Delphi Step 1, by the Percent Agreement method, were: presentation screens (87\%); programmatic content (87\%); introduction (87\%); hand hygiene (87\%); vascular catheters $(87 \%)$; peripheral venous catheter (100\%); central venous catheter (100\%); preparation and administration of medications (100\%); and completion (100\%). Content screens on infusion systems and accessories (62\%), specific parenteral solutions (75\%) and the main complications (62\%) presented agreement lower than $80 \%$; thus, we discussed them with the judges in Delphi Step 2, along with other points that the judges resumed at the meeting because they marked them as relevant.

To define the requirements for elaborating the structure of the Virtual Learning Object, first, we selected and stratified content according to the theme specificity. This material constituted the basis for textual production of the screens and elaboration of the media.

The development of the Virtual Learning Object platform was carried out by the laboratory of web design LOOP, with its prototypes and tests, graphic definition and dimension of images and videos. The "CuidarTech" platform is exclusive to the Health and Nursing Technologies Laboratory and maintains its logo.

Regarding the videos elaborated, there was the placement of the audio description feature corresponding to the actions presented. For this, explanatory scripts and contents were elaborated and recorded. We captured the images and videos at the hospital institution of the study, as well as the images made. Figures 1 and 2 show models of the online course screens on the "CuidarTech" platform.

Chart 1 - Structure of the Virtual Learning Object content on control and prevention of bloodstream infection associated with infusion therapy, Vitória, Espírito Santo, Brazil, 2019

\begin{tabular}{|c|c|c|}
\hline \multicolumn{3}{|c|}{ Virtual Learning Object: control and prevention of bloodstream infection associated with infusion therapy } \\
\hline Modules & Objective & Subjects covered \\
\hline Presentation & $\begin{array}{l}\text { To guide on the Virtual Object, teaching } \\
\text { strategies and instructions on the platform }\end{array}$ & $\begin{array}{l}\text { 1) General guidelines for the realization of the course and its content } \\
\text { 2) Pre-test: } 21 \text { multiple choice questions }\end{array}$ \\
\hline Introduction & $\begin{array}{l}\text { To introduce Virtual Object modules and } \\
\text { conceptual map }\end{array}$ & $\begin{array}{l}\text { 1) Programmatic Content of the Virtual Object } \\
\text { 2) Concepts related to bloodstream infection (BSI) } \\
\text { 3) Physiopathogeny of infections associated with intravascular catheter } \\
\text { 4) Risk factors for HAls }\end{array}$ \\
\hline Prevention measures & $\begin{array}{l}\text { To portray essential guidelines for } \\
\text { procedures related to venous catheters and } \\
\text { infusion therapy }\end{array}$ & $\begin{array}{l}\text { 1) Hand hygiene }(\mathrm{HH}) \\
\text { 2) Types of vascular catheters } \\
\text { 3) Flushing and Lock }\end{array}$ \\
\hline Peripheral venous catheter & $\begin{array}{l}\text { To guide best practices for insertion, } \\
\text { maintenance, and removal of the peripheral } \\
\text { catheter }\end{array}$ & Main recommendations for peripheral catheters \\
\hline Central venous catheter & $\begin{array}{l}\text { To guide best practices for insertion, } \\
\text { maintenance, and removal of the central } \\
\text { venous catheter. }\end{array}$ & Main recommendations for central catheters \\
\hline Infusion therapy & $\begin{array}{l}\text { To guide best practices related to infusion } \\
\text { therapy }\end{array}$ & $\begin{array}{l}\text { 1) Infusion systems and accessories } \\
\text { 2) Medicines: preparation and administration } \\
\text { 3) Specific parenteral solutions } \\
\text { 4) Main related complications }\end{array}$ \\
\hline Course completion & Complete Virtual Object content & 1) Post-test: 21 multiple choice questions \\
\hline
\end{tabular}




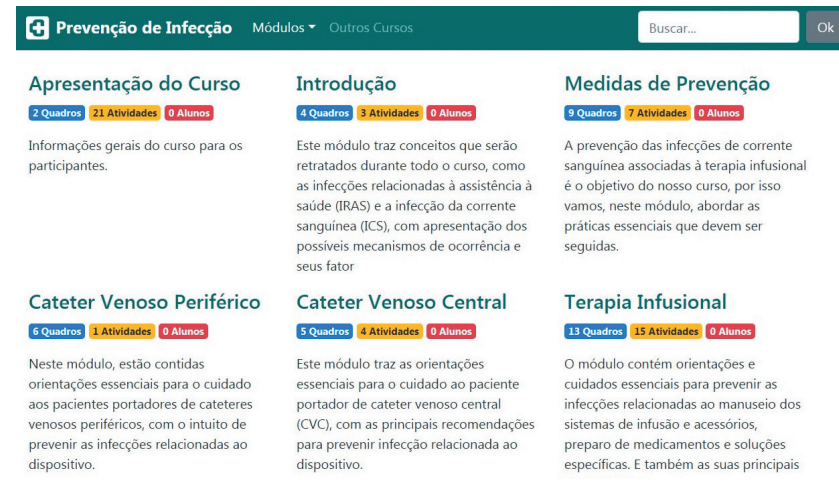

Figure 1 - Presentation screen of the Online Course modules, Vitória, Espírito Santo, Brazil, 2019

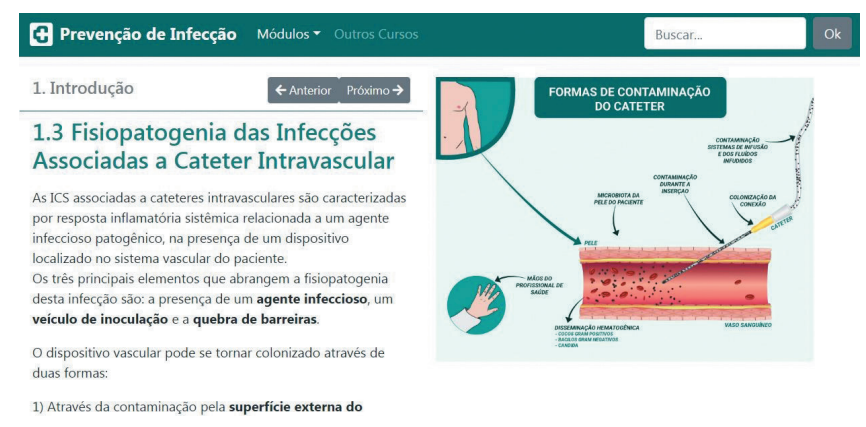

Figure 2 - Screen of the module "Introduction - Physiopathogeny of Infections Associated with Intravascular Catheter", Vitória, Espírito Santo, Brazil, 2019

\section{DISCUSSION}

The present study presented challenges to constructing and assessing the Virtual Learning Object to the Control and Prevention of Bloodstream Infection Associated with Infusion Therapy. These challenges were standardized and streamline the essential guidelines for health professionals, provide new experiences in the process of knowledge acquisition and, consequently, promote the reduction of the risks of the patient acquiring a bloodstream infection related to infusion therapy.

The analysis of the judges was fundamental for obtaining an adequate and comprehensive Virtual Learning Object in its content through the Delphi technique, which is a method used to deduce and refine the opinions of a group of experts to achieve the consensus of ideas ${ }^{(16)}$. Thus, educational technology needs appropriate pedagogical and technical approaches, based on its construction and evaluation, to elaborate a technological material with effective educational objectives. Furthermore, we point out the importance of assessment for the development of the media based on a dynamic and structured pedagogical foundation ${ }^{(17)}$.

The results obtained in the process of assessing the Virtual Learning Object content indicated reliability. The analysis based on the expert judges contributed to the construction of the material to the extent that they suggested changes and inclusions of relevant items to each theme. We incorporated all suggestions into the instanced content so that they favored success in the production of the online course.

In the care practice, there is a positive impact of virtual educational technologies on nursing care related to the presence of adverse events. A study on the incidence and prevalence of pressure injuries in an adult intensive care unit observed a positive difference in care after applying for nurses the online education tool, which optimized the early diagnosis of risk factors and the early identification of the injury onset ${ }^{(18)}$. Another study on the recognition and recording of adverse events in hemodialysis evaluated the knowledge of nursing technicians before and after face-to-face classroom and distance learning interventions. The study concluded that the two ways of training increased their knowledge, reflected in the improvement of data on adverse events acquisition, and, in turn, developed the quality of patient safety ${ }^{(19)}$.

In educational practice, the use of Virtual Learning Object demonstrated satisfactory results from nursing students and specialists about the process of learning flexibly and interactively ${ }^{(20)}$. Thus, "the use of hypermedia in nursing education has contributed to the development of a student-centered educational process, adapting to their needs, cognitive style and rhythm" (p. 226) ${ }^{(21)}$.

From the perspective of using blended learning and the flipped classroom, which are a combination of learning theories, along with current concepts, which encourage the Virtual Learning Object to present itself as an educational technology as the basis for the teaching and learning process( ${ }^{(22)}$, is a useful tool for in-service training ${ }^{(20)}$. In this context, a study about constructing a teaching platform on the nursing process aims at this thought transformation. It reaffirms students' role as autonomous individuals, responsible for their learning, which receives help from the teacher and the various didactic-pedagogical tools, with a view to the development of their clinical and reflective reasoning ${ }^{(23)}$.

The Virtual Learning Object proposes information dissemination and interest stimulus regarding the scientificity of standard practices related to infusion therapy. It presents recommendations of preventive measures through an assembled didactic structure, characterized in an active, attractive, practical, and organized way. This structure includes self-instruction criteria, to enable the student/professional autonomy during the use of the appropriate means to obtain new knowledge, with the aid of multimedia tools.

\section{Study Limitations}

As a limitation, we highlight the need to assess together with the target audience the appearance and usability of the Virtual Object.

\section{Contributions to the fields of Nursing, Health, or Public Policies}

To stimulate the interest of health managers, nurses, and future nursing professionals in developing new educational technologies for in-service training. Educational technologies which have new perspectives for alignment of nursing theoretical and practical knowledge and that lead to the improvement of health care quality, aiming at modernity, dynamism, and efficiency.

\section{FINAL CONSIDERATIONS}

The Virtual Learning Object on control and prevention of bloodstream infection associated with infusion therapy was organized 
into five modules and 39 content screens, which integrate the main recommendations and contain images, hypertexts, videos, case studies, and quiz, through an exclusive platform. The content assessment reached an index higher than $85 \%$ among the judges, indicating the quality and adequacy of the content.

This research used the User-Centered Design method for construction and Delphi panel to assess the content of a Virtual Learning Object, presenting the necessary steps. We highlight the importance of partnerships and interdisciplinary teams in the realization of this type of study, which had a group of design, pedagogy, linguistics, and health professionals.

Considered a technological innovation in health, because it encompasses a comprehensive content, based on the main national and international references, we expect that the course will be a motivating and satisfactory alternative to health education, with the ability to optimize the dissemination of information on measures to prevent bloodstream infection and, consequently, provide patient safety.

\section{REFERENCES}

1. World Health Organization (WHO). Guidelines on core components of infection prevention and control programmes at the national and acute health care facility level. Geneva:World Health Organization [Internet]. 2016 [cited 2019 Jan 20]. Available from: https://www.who.int/gpsc/ ipc-components-guidelines/en/

2. Fortaleza CMCB, Padoveze MC, Kiffer CRV, Barth AL, Carneiro ICDRS, Giamberardino HIG, et al. Multi-state survey of healthcare-associated infections in acute care hospitals in Brazil. J Hosp Infect. 2017;96(2):139-44. doi: 10.1016/j.jhin.2017.03.024

3. Vasudeva N, Nirwan PS, Shrivastava P. Bloodstream infections and antimicrobial sensitivity patterns in a tertiary care hospital of India. Ther Adv Infect Dis. 2016;3(5):119-27. doi: 10.1177/2049936116666983

4. Mermel LA. Short-term peripheral venous catheter-related bloodstream infections: a systematic review. Clin Infect Dis. 2017;65(10):175762. doi: $10.1093 /$ cid/cix562

5. Lopez JL, Vilela AA, Palacio EF, Corral JO, Marti CB, Portal PH. Indwell times, complications and costs of open vs closed safety peripheral intravenous catheters: a randomized study. J Hosp Infect. 2014;86(2):117-26. doi: 10.1016/j.jhin.2013.10.008

6. Bell T, O'Grady NP. Prevention of central line-associated blood stream infections. Infect Dis Clin N Am. 2017;31(3):551-9. doi:10.1016/j. idc.2017.05.007

7. Band JD, Gaynes R. Prevention of intravascular catheter-related infections. UpToDate [Internet]. 2018 [cited 2018 Apr 20]. Available from: https://www.uptodate.com/contents/intravascular-catheter-related-infection-prevention

8. Massaroli A, Martini JG, Moya JLM, Bitencourt JVOV, Reibnitz KS, Bernardi MC. Teaching of infection control in undergraduate courses in health sciences: opinion of experts. Rev Bras Enferm. 2018;71(Suppl4):1626-34. doi: 10.1590/0034-7167-2017-0928

9. Salvador PTCO, Bezerril MS, Mariz CMS, Fernandes MID, Martins JCA, Santos VEP. Virtual learning object and environment: a concept analysis. Rev Bras Enferm. 2017;70(3):572-9. doi: 10.1590/0034-7167-2016-0123

10. Frota NM, Barros LM, Araujo TM, Lopes MVO, Almeida PC, Caetano JA. Validation of educational hypermedia about peripheral venipuncture. Texto Contexto Enferm [Internet]. 2015 [cited 2020 Mar 1];24(2):353-61. Available from: http://www.scielo.br/pdf/tce/v24n2/pt_0104-0707tce-24-02-00353.pdf

11. Antonio Jr W. Objetos virtuais de aprendizagem como recursos digitais educacionais. Pedag Foco, 2016[cited 2018 Apr 07];11(5):53-65 Available from: http://revista.facfama.edu.br/index.php/PedF/article/view/187

12. Castro Silva LT, Almeida DF, Laerte GT, Miranda MR, Bezerra CR. Percepções de estudantes de enfermagem sobre educação a distância. Cien Enferm. 2016;22(2):129-39. doi: 10.4067/S0717-95532016000200010

13. Braga CSR, Andrade EMLR, Luz MHBA, Monteiro AKC, Campos MOB, Silva FMS, et al. Construction and validation of a virtual learning object on intestinal elimination stoma. Invest Educ Enferm. 2016;34(1):120-7. doi: 10.17533/udea.iee.v34n1a14

14. Associação Brasileira de Normas Técnicas. NBR 16982: ergonomia da interação humano-sistema: métodos de usabilidade que apoiam o projeto centrado no usuário. Rio de Janeiro, 2014.

15. Alexandre NMC, Coluci MZO. Validade de conteúdo nos processos de construção e adaptação de instrumentos de medidas. Ciên Saúde Coletiva. 2011;16(7):3061-8. doi: 10.1590/S1413-81232011000800006

16. Marques JB, Freitas D. The DELPHI method: characterization and potentialities for educational research. Rev Pro-posições. 2018;29(2):389415. doi: 10.1590/1980-6248-2015-0140

17. Salvador PTCO, Santos MCM, Fortes VA, Ferreira Jr MA, Fernandes MID, Martins JCA, et al . Validação de Objeto Virtual de Aprendizagem para apoio ao ensino da sistematização da assistência de enfermagem. Rev Bras Enferm. 2018;71(1):11-9. doi: 10.1590/0034-7167-2016-0537

18. CaldiniLN, Araújo TM, Frota NM, Barros LM, Silva LA, Caetano JA. Evaluation of educational technology on pressure injury based on assistance quality indicators. Rev Rene. 2018;19:e32695. doi: 10.15253/2175-6783.20181932695

19. Pássaro PG, D'ávila R. Nursing educational intervention for the identification of Adverse Events in hemodialysis. Rev Bras Enferm. 2018;71(Suppl 4):1507-13. doi: 10.1590/0034-7167-2017-0843

20. Alvarez AG, Dal Sasso GTM, lyengar S, Schmitt, Andrade DF. Quality analysis of the virtual learning object for nursing pain assessment.Rev Cuba Enferm [Internet]. 2018 [cited 2019 Apr 10];34(3). Availablefrom: http://www.revenfermeria.sld.cu/index.php/enf/article/view/1447 
21. Luna IT, Pinheiro PNC, Teixeira FO. Hypermedia for teaching nursing in a digital learning environment. Braz J Technol[Internet]. 2018 [cited 2019 Apr 10];1(2):209-31. Available from: http://www.brjd.com.br/index.php/BJT/article/view/747

22. Salvador PTCO, Rodrigues CCFM, Ferreira Jr MA, Fernandes MID, Martins JCA, Santos VEP. Construction of hypermedia to support the systematization of the nursing care education. Rev Gaúcha Enferm. 2019;40:e20180035. doi: 10.1590/1983-1447.2019.20180035

23. Melo ECA, Enders BC, Bastos ML. PlataformaPEnsinar ${ }^{\oplus}$ : a learning tool for teaching the nursing process. Rev Bras Enferm. 2018;71(Suppl 4):1522-30. doi: 10.1590/0034-7167-2016-0411 